\title{
The Constitution of Hong Kong human rights protection mechanisms
}

\author{
Taixia Shen \\ Law School/Intellectual Property School, Jinan University, Guangzhou 510632, China. \\ Sunbird726@hotmail.com
}

Keywords: Human Rights, Protection Mechanisms, Hong Kong Courts, The Office Of The Ombudsman, The Equal Opportunities Commission, The Office Of The Privacy Commissioner For Personal Data

\begin{abstract}
This paper studies the constitution of human rights protection mechanisms in Hong Kong. It mainly includes the jurisdictional protection, administrative protection and the protection by the NGOs. The judges, the Office of The Ombudsman, the Equal Opportunities Commission, the Office of the Privacy Commissioner for Personal Data and the NGOs on human rights are the main organizations. These organizations have their own characters and systems for protecting human rights, which are the key parts of Hong Kong human rights protection mechanisms.
\end{abstract}

\section{Introduction}

Hong Kong did not have the systematic legislations nor mechanisms for protecting human rights for most of the time in British colonial period. Hong Kong had entered into the transition period after the implementation of the Sino-British Joint Declaration (formally known as the Joint Declaration of the Government of the United Kingdom of Great Britain and Northern Ireland and the Government of the People's Republic of China on the Question of Hong Kong) in 1985. There is great progress on the protection of human rights during this period. The Government of Hong Kong has made numerous laws for promoting human rights and has established the administrations and mechanisms to carry out and supervise these laws. In 1986, the Hong Kong Basic Law was begun to be drafted by the Central Government of China, and the draft was completed in 1990. Hong Kong Bill of Rights Ordinance came into force on 8 June 1991, the Sex Discrimination Ordinance, the Disability Discrimination Ordinance and The Family Status Discrimination Ordinance are implemented from 1995 to 1998. The Personal Data (Privacy) Ordinance became effective in 1996. The various public bodies including the Office of the Ombudsman, the Equal Opportunities Commission, the Office of the Privacy Commissioner for Personal Data were created to monitor the relative laws. In addition, non-governmental organizations (NGOs) on human rights have been progressively established in civil society, and have made great contributions to the protection of human rights.

\section{Jurisdictional protection of human rights}

Hong Kong has the tradition of common law system which attaches importance to the jurisprudences, the role of judiciary for protecting human rights is extremely important, the mechanisms of jurisdictional protection includes the individual application mechanism and the judicial review mechanism.

\subsection{Individual applications mechanism}

Hong Kong neither has an independent human rights court nor a constitutional court. All the courts may hear cases on human rights issues. According to the section 6 and section 7 of the Hong Kong Bill of Rights Ordinance, the individuals have the rights to appeal in the courts and the courts may grant a remedy, or make an order, in respect of violation of this Ordinance. However, the Ordinance binds only (a) the Government and all public authorities; and (b) any person acting on behalf of the Government or a public authority. 
In practice, there are many individual application concerning the right to abode, freedom of expression, equality and non-discrimination, torture or inhumane treatment, personal freedom and security, fair trial right, presumption of innocence, etc. Analyzing the cases examined by the Hong Kong Court of Final Appeal, the rights involved are related to many provisions of the Hong Kong Basic Law and the Hong Kong Bill of Rights Ordinance. The judges summarize the principles and jurisprudences on base of the human rights cases, which are the important sources of common law [1].

\subsection{Judicial review mechanism}

Hong Kong courts have established juridical review mechanism before Hong Kong returned to the mainland of China. The case of R v. Sin Yau Ming[2] in 1991 opened the time of judicial review system in Hong Kong, which affirmed the supreme status of the Hong Kong Bill of Rights Ordinance. The Hong Kong Basic Law replaced the Letters Patent and has been to be the supreme law which is as the constitutional law in Hong Kong since 1997. The Hong Kong courts have judicial review power, they can examine the legislations and the administrative acts whether they are inconsistent with the Hong Kong Basic Law. The courts can anounce the legsilations and the administrative acts invalid if they contradict the human rights provisions of the Hong Kong Basic Law . With this judicial review mechnism, the courts not only can protect human rights in the individul cases, but they also give the remedy to individuls by anouncing the legislations and administrative acts invalid which are opposite to the the Hong Kong Basic Law . For exmaple, in the leading case of the HKSAR v. Leung Kwok Hung and Others[3], the Hong Kong Court of Final Appeal affirmed the judicial review system, that Hong Kong courts have the power to examine whether the legislative acts and administrative acts violate the human rights provisions of the Hong Kong Basic Law and the International Covenant on Civil and Political Rights recognized in Article 39 of the Hong Kong Basic Law.

Besides jurisdictional protection of human rights, the administraive protection is also neccessary.

\section{Administrative protection of fundamental rights}

Hong Kong has established several public authorities to protect human rights, the main authorities are the Office of the Ombudsman, the Equal Opportunities Commission and the Office of the Privacy Commissioner for Personal Data.

\section{The Office of the Ombudsman and its mechanism}

The Office of the Ombudsman which is established in 1989 according to the "Ombudsman Ordinance". It serves to control public power in Hong Kong. The Office of the Ombudsman strives to improve the quality and culture of public service by independent, objective and impartial investigation into complaints received or by own initiative studies.

According to the Ombudsman Ordinance, the Office of the Ombudsman has the power to investigate complaints from aggrieved persons about maladministration by the government departments/agencies and public bodies listed in Part I of Schedule 1 to the Ombudsman Ordinance; to investigate complaints against government departments/agencies for non-compliance with the Code on Access to Information, including the organisations listed in Part II of Schedule 1; and to launch the direct inquiry, of its own will, on the matters concerning wide public interests. In accordance with the Ombudsman Ordinance, the Ombudsman has a wide range of investigative powers such as obtaining information and documents, summoning witnesses and inspecting premises of organizations under complaint. The Ombudsman may report his findings and make recommendations to the corresponding organizations. The leaders of organizations have a duty to report at regular intervals on their progress in implementing the recommendations of the Ombudsman. Investigation, mediation and a full investigation are the three main methods of dealing with the complaints. During mediation, the Ombudsman often promotes conciliation; it makes the investigation or full investigation if the conciliation cannot be carried out. 
Generally, the Ombudsman has the jurisdiction to control or supervise all government departments of the Hong Kong except the Hong Kong Police and the Independent Commission against Corruption (ICCC). However, the Ombudsman has jurisdiction if they offend the Code on Access to Information. Indeed, the Office of the Ombudsman fulfills its mission of protecting human rights by making inquiries and recommendations.

\subsection{The Committee on Equal Opportunities and its mechanism}

In 1996, the Equal Opportunities Commission (hereinafter the EOC) was established in accordance with the Sex Discrimination Ordinance, the EOC is responsible for Implementing and monitoring the anti-discrimination legislations, especially the Sex Discrimination Ordinance, the Disability Discrimination Ordinance, the Family Status Discrimination Ordinance and the Race Discrimination Ordinance.

The EOC is committed to the elimination of discrimination on the grounds of sex, marital status, pregnancy or race; it promotes the equality of opportunities between men and women, between persons with and without a disability and irrespective of family status and race. It also aims to eliminate sexual harassment, and harassment and vilification on the grounds of disability and race.

The powers and mechanisms of the EOC for safeguarding human rights are as follows: (1) to conduct an investigation in accordance with the complaint and encourage both of the parties of conflict to get into mediation; (2) to investigate the situation and the issue of discrimination; (3) in accordance with the relevant legislation, to draw up the practical guide of these relevant law; (4) to promote the implementation of legislation, to give the opinions on amendments to anti-discrimination legislation, to carry out the research on discrimination and equal opportunities, and to promote public education in order to achieve equal opportunities; (5) to disclaimer for the public interest. The most well-known case is the EOC V. The director of the Department of Education.

\subsection{The Office of the Privacy Commissioner for Personal Data and its mechanism}

The Privacy Commissioner for Personal Data (hereafter the PCPD) is an independent public law body established in 1996 and to oversee the enforcement of the Personal Data (Privacy) Ordinance. In Hong Kong, if an individual suspects that his or her privacy rights or personal data are violated or abused, he or she should firstly contact the interested party which abuse his or her personal information. If he or she is not satisfied with the response of the concerning party, he or she can file in a complaint form with the supporting evidences. A complaint must be in writing in Chinese or English or in another form accepted by the Commissioner and must specify the act or practice complained of and the data user involved. After receiving a complaint and verifying the identity of the complainant, the PCPD will first consult with the complainant and the party complained against to, it will determine whether a prima facie case can be established. If there is a prima facie case, the PCPD will try to resolve the dispute through conciliation. If the dispute cannot be resolved through conciliation, the PCPD may carry out a formal investigation. The Commissioner may also immediately proceed to undertake a formal investigation if the suspected contravention in the complaint case is of a serious nature. Apart from criminal sanctions that can be imposed on a data user that has contravened the Ordinance, if an individual believes that he or she has suffered damage, he or she has the right to seek compensation from the data users concerned through civil proceedings. Since the establishment of the PCPD, the number of complaints received and the number of inquiries increased. In recent years, the number of complaints has been nearly 1,000 per year, and the number of inquiry cases is 10,000 per year [4].

In addition, there are special supervising authorities and systmes within the Hong Kong Police and the Independent Commission against Corruption (ICCC). The legal aid system is also established.

\section{Protection of human rights by the NGOS}

Non-governmental organizations (NGOs) on human rights in Hong Kong are important to control public powers. According to the third report submitted by the Hong Kong SAR under article 40 of the CCPR (CCPR/C/CHN-HKG/3), there are more than 100 NGOs on human rights in Hong Kong. The 
most representative NGOs are the Hong Kong Human Rights Monitor and the Hong Kong Human Rights Commission.

\subsection{Hong Kong Human Rights Monitor and its mechanism}

The Hong Kong Human Rights Monitor (hereafter the HKHRM) is established in 1995. Its purpose is to promote human rights in Hong Kong. Apart from a few full-time staff, most of the HKHRM's work is carried out by its volunteer members; its members are from many different backgrounds. The main types of work are as follow:(1) to monitor the law, policies and actions of the public authorities, and to publish on various human rights issues and the rule of law; (2) to summarize the human rights issues to the press, the UN, and foreign governments;(3) to carry out the research on various important subjects including polices, immigration law, constitutional issues and freedoms of association, assembly and expression, etc. (4) to promote human rights education, it publishes human rights materials in Chinese or English including a newsletter, human rights booklets; (5) to work on the individual cases, the HKHRM deals with the cases mentioned by other NGOs which has strong implications for legal or institutional reforms in some areas, especially on the immigration issues, etc.

In recent years, the HKHRM has great contributions for protecting human rights. It submitted some reports to United Nations Human Rights Council on the fulfillment of the international human rights treaties by the governments of the UK and Hong Kong within their territories; it frequently met with government officials and international organizations, the monitor members have previously met with the Chief Executive of Hong Kong (Donald Tsang) and Governor to discuss a re-examination of police interrogation and complaint procedures; it participated in legislative hearings on various human rights issues including equal opportunities legislations; it reviewed the Hong Kong's immigration laws and practice from a human rights perspective; it helped the Hong Kong People's Council on Public Housing Policy and social workers' groups to promote housing rights.[5]

\subsection{The Hong Kong Human Rights Commission and its mechanism}

The Hong Kong Human Rights Commission (hereafter the HKHRC) is a coalition of eleven NGOs, including religious, community and students' and women's groups. It was founded in 1988. Since it was founded, in addition to lobbying for the Hong Kong Bill of Rights Ordinanc and subsequent amendments to the law at local level, the HKHRC has also been submitting reports to UN treaty bodies, attending hearings and lobbying at international level. It has promoted human rights education through exhibitions, gatherings in schools and community centers. In rencent years, the HKHRC has tried to promote and protect the human rights of the community, it has gathered resources to consolidate the power in the civil society.

In addition, Human Right Watch, the Hong Kong Bar Association, the Hong Kong Human Rights Front Unison, The Lobby Group and the International Disability Alliance are the important NGOs on human rights in Hong Kong for protecting human rights. Each of civil human rights organizations has its own purpose of activities to promote and protect human rights in Hong Kong. These NGOs have persistent commitment to human rights and sometimes cooperate with the government.

\section{Conclusion}

Hong Kong has established a number of organizations and mechanisms to implement and supervise Hong Kong's human rights law. The courts protect human rights, supervise and safeguard the Hong Kong Basic Law and various human rights laws through individual applications system and judicial review mechanism. The Office of The Ombudsman, the Equal Opportunities Commission and the Office of the Privacy Commissioner for Personal Data provide reliefs to those whose human rights have been infringed by the government and others. Besides, Hong Kong government has also set up legal aid services. In addition, in the civil society of Hong Kong, there are the NGOs on human rights, they are the important organizations for protecting and promoting human rights. Evidently, there are some problems in all of organizations and their mechanisms for protecting human rights in Hong Kong. These Institutions and mechanisms have their own limitations in the protection and promotion of 
human rights, they need to be improved and perfected in future. However, Hong Kong has comprehensive human rights protection mechanisms, and it has rich experiences for us to learn.

\section{Acknowledgments}

This paper is the result of the National Social Science Fund Youth Project entitled "Research on judicial protection mechanisms for human rights in Hong Kong SAR "(No. 15CFX016).

\section{References}

[1]. Young, SNM. Constitutional Rights in Hong Kong's Court of Final Appeal, Chinese (Taiwan) Yearbook of International Law and Affairs. Vol. 27(2011), p. 67-96.

[2]. R v. Sin Yau Ming, CACC289/1990.

[3]. HKSAR v. Leung Kwok Hung and Others, FACC4/1999.

[4]. Information on: https://www.pcpd.org.hk/sc_chi/complaints/statistics/statistics.html.

[5]. Information on: http://www.hkhrm.org.hk/simplified/index.html. 